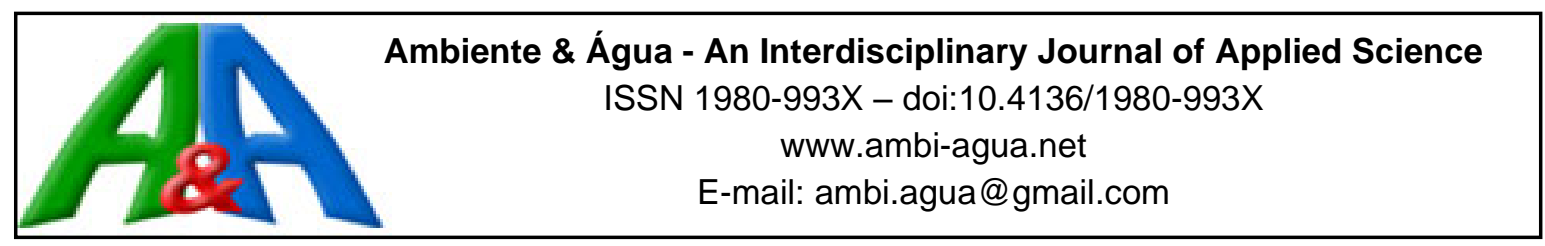

\title{
Photochemical efficiency in pineapple plants under saline water irrigation
}

\author{
ARTICLES doi:10.4136/ambi-agua.2564
}

Received: 22 Apr. 2020; Accepted: 28 Jul. 2020

\author{
Cleiton Fernando Barbosa Brito ${ }^{1 *}$; ; Varley Andrade Fonseca1(D; \\ Marcelo Rocha dos Santos ${ }^{2}$; Sérgio Luiz Rodrigues Donato ${ }^{2}$; \\ Alessandro de Magalhães Arantes ${ }^{\text {iD }}$; Aloísio José dos Santos² \\ 1Departamento de Ciências Agrárias. Universidade Estadual de Montes Claros (UNIMONTES), Caixa Postal 91, \\ CEP: 39440-000, Janaúba, MG, Brazil. E-mail: varley.ibce@ig.com.br \\ ${ }^{2}$ Setor de Agricultura. Instituto Federal de Educação, Ciência e Tecnologia Baiano (IFBaiano), Caixa Postal 09, \\ CEP: 46430-000, Guanambi, BA, Brazil. E-mail: marcelo.rocha@ifbaiano.edu.br, \\ sergio.donato@guanambi.ifbaiano.edu.br, alessandro.arantes@guanambi.ifbaiano.edu.br, \\ aloisio.santos@ifbaiano.edu.br \\ *Corresponding author. E-mail: cleiton.ibce@ hotmail.com
}

\begin{abstract}
Studies determining physiological characteristics of field-grown pineapples irrigated with low-quality water are lacking. This work evaluated the photochemical efficiency of 'Pérola' pineapple irrigated with saline water in the semiarid region of Bahia, Brazil. The experiment was carried out in randomized blocks with five treatments consisting of the following irrigation depths: $100 \%$ of $\mathrm{ET}_{\mathrm{c}}$ using water with electrical conductivity $\left(\mathrm{EC}_{\mathrm{w}}\right)$ of $0.75 \mathrm{dS} \mathrm{m}^{-1}$; and 50,75 , 100 and $125 \%$ of $\mathrm{ET}_{\mathrm{c}}$ using water with $\mathrm{EC}_{\mathrm{w}}$ of $3.6 \mathrm{dS} \mathrm{m}^{-1}$. Chlorophyll $a$ fluorescence measurements were made over the course of 13 months using a pulse-modulated fluorometer, in all treatments. Quantum efficiency $(\mathrm{Fv} / \mathrm{Fm})$ fluctuated throughout the cycle of the pineapple with values below the ideal, especially at the end of the crop cycle. Quantum yield of photosystem II (Yield), photochemical quenching ( $\left.\mathrm{q}_{\mathrm{P}}\right)$, non-photochemical quenching (NPQ) and chlorophyll fluorescence decrease ratio $\left(\mathrm{R}_{\mathrm{Fd}}\right)$ were not influenced by irrigation depths. Therefore, energy used for photosynthetic processes in pineapple plants is not affected by irrigation using saline water with electrical conductivity of $3.6 \mathrm{dS} \mathrm{m}$.
\end{abstract}

Keywords: Ananas comosus, CAM plants, chlorophyll fluorescence, salinity.

\section{Eficiência fotoquímica em plantas de abacaxi sob irrigação com água}

\section{RESUMO}

São escassos estudos que determinem as características fisiológicas do abacaxizeiro, em condições de campo, irrigadas com água de qualidade inferior. Assim, objetivou-se avaliar eficiência fotoquímica em abacaxizeiro 'Pérola' irrigado com água salina no semiárido baiano. $\mathrm{O}$ experimento foi conduzido em blocos casualizados com cinco tratamentos representados pelas lâminas de irrigação: $100 \%$ da $\mathrm{ET}_{\mathrm{c}}$ com água de condutividade elétrica $\left(\mathrm{CE}_{\mathrm{a}}\right)$ de $0,75 \mathrm{dS}$ $\mathrm{m}^{-1}$ e 50, 75, 100 e $125 \%$ da $\mathrm{ET}_{\mathrm{c}}$ com aplicação de água de $\mathrm{CE}_{\mathrm{a}}$ de $3,6 \mathrm{dS} \mathrm{m}^{-1}$. As leituras da fluorescência da clorofila "a" foram realizadas durante 13 meses através de fluorômetro de luz modulada, em todos os tratamentos. Verificou-se que a eficiência quântica (Fv/Fm) variou ao

This is an Open Access article distributed under the terms of the Creative Commons Attribution License, which permits unrestricted use, distribution, and reproduction in any medium, provided the original work is properly cited. 
longo do ciclo do abacaxizeiro com valores abaixo do ideal, principalmente, no final do ciclo. As variáveis rendimento quântico do fotossistema II (Yield), dissipação fotoquímica (qP), dissipação não-fotoquímica (NPQ) e taxa de redução de fluorescência $\left(\mathrm{R}_{\mathrm{Fd}}\right)$ não foram influenciadas pelas lâminas de irrigação avaliadas. Portanto, a utilização da energia nos processos fotossintéticos de plantas de abacaxizeiro não são influenciados pela irrigação com lâminas de água salina com condutividade elétrica de $3,6 \mathrm{dS} \mathrm{m}^{-1}$.

Palavras-chave: Ananas comosus, Fluorescência da clorofila, plantas CAM, salinidade.

\section{INTRODUCTION}

Pineapples (Ananas comosus L. Merril) are economically exploited in most Brazilian states, making an important contribution to employment and income generation (Franco et al., 2014), in which the states of Pará, Paraíba, Minas Gerais and Bahia are the biggest producers. In the state of Bahia, the municipality of Itaberaba stands out as the main producer (IBGE, 2020) and is located in the semi-arid region of the state.

In this context, the pineapple can become an alternative crop for other semiarid regions (Mota et al., 2016) since it has the potential of maintaining its yield under hotter and drier climates (Borland et al., 2014) owing to its crassulacean acid metabolism (CAM) (Zhang et al., 2014; Couto et al., 2016). CAM plants save water by closing their stomata during the day and opening them during the night with $\mathrm{CO}_{2}$ fixation, resulting in better water-use efficiency in dry conditions (Carr, 2012).

Studies were developed for irrigated pineapple grown in semiarid regions (Franco et al., 2014; Pegoraro et al., 2014; Maia et al., 2016); however, information about physiological characteristics of this crop irrigated with saline water is lacking, making field studies with pineapple subjected to saline conditions necessary (Elhag and Elzain, 2012).

Chlorophyll $a$ fluorescence is a non-invasive analysis that allows collecting data from the efficiency of the photochemistry stage of photosynthesis (Light or hill reaction) and hence is a reliable source of information about plant condition, especially under abiotic stress conditions (Murchie and Lawson, 2013; Goltsev et al., 2016).

Studies about physiological characteristics of pineapple in regard to fluorescence were mainly carried out in controlled environments such as greenhouses and laboratory, in vitro, using only plantlets (Vieira et al., 2010; Cruz et al., 2014; Couto et al., 2016). Thus field research into chlorophyll fluorescence comprising the whole pineapple cycle is much needed.

Fluorescence determination under field conditions can be useful for studies on physiological behavior of CAM plants (Díez et al., 2017), such as the pineapple, thereby shedding some light on the crop adaptability in context of the semiarid region. Therefore, this study evaluated photochemistry efficiency in 'Pérola' pineapple submitted to irrigation with saline water and water stress in the semiarid region of Bahia, Brazil.

\section{MATERIAL AND METHODS}

The study was carried out in an experimental area at the Federal Institute Baiano, Guanambi campus, located in the Irrigated Perimeter of Ceraíma, municipality of Guanambi, Bahia, Brazil. The mean annual rainfall depth of the region was $680 \mathrm{~mm}$, and the mean annual temperature was $26^{\circ} \mathrm{C}$. During the experimental period, there was a maximum average temperature $\left(\mathrm{T}_{\max }\right)$ of $32.07^{\circ} \mathrm{C}$ and a minimum averager temperature $\left(\mathrm{T}_{\min }\right)$ of $21.95^{\circ} \mathrm{C}$, relative humidity $(\mathrm{RH})$ of $55.65 \%$, gust wind of $46.70 \mathrm{~km} \mathrm{~h}^{-1}$, reference evapotranspiration $\left(\mathrm{ET}_{\mathrm{o}}\right)$ of $5.68 \mathrm{~mm} \mathrm{dia}^{-1}$ and a rain total of $728 \mathrm{~mm}$ (Figure 1).

Rev. Ambient. Água vol. 15 n. 5, e2564 - Taubaté 2020 

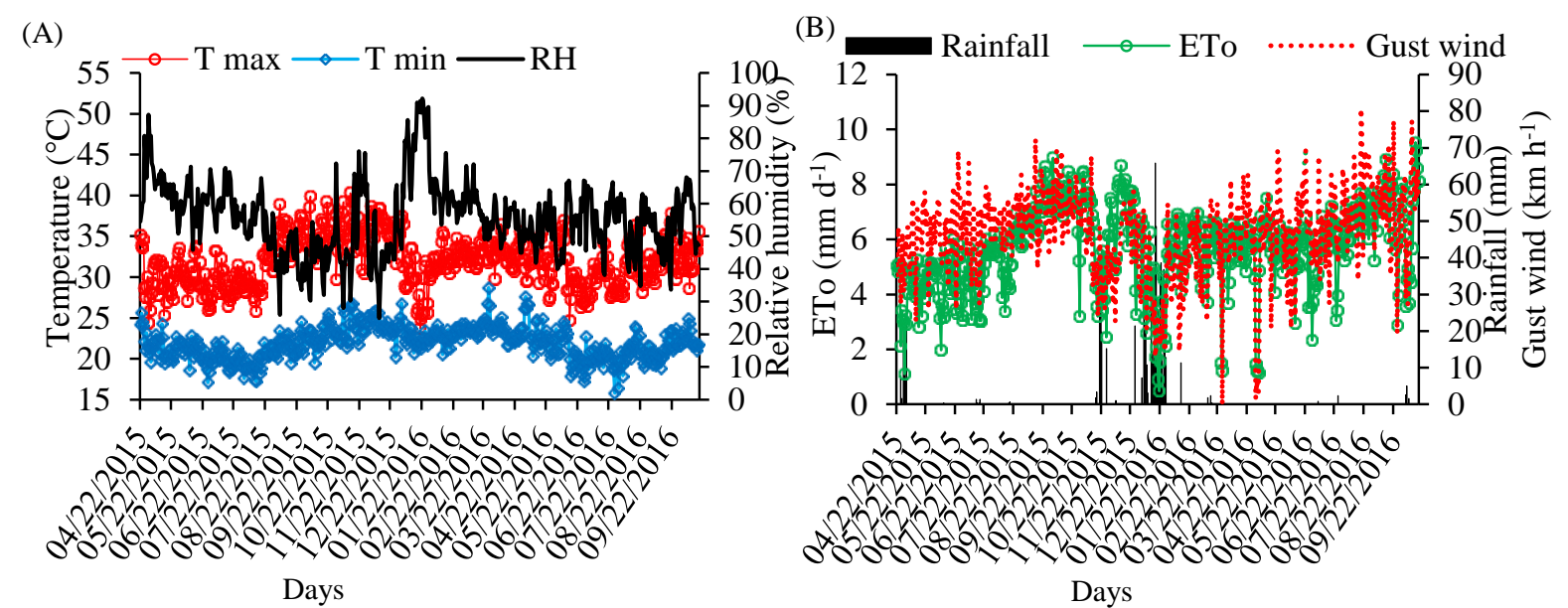

Figure 1. Temperature (maximum-Tmax and minimum-Tmin) and relative air humidity (RH) (A), gust wind speed, rainfall and reference evapotranspiration $\left(\mathrm{ET}_{\mathrm{o}}\right)(\mathrm{B})$ during the experimental period.

Pineapples were cultivated in a typic dystrophic Red Yellow Latosol, with weak A horizon, on flat to gently undulating relief. The soil chemical characteristics (Tedesco et al., 1995) in the layer of 0-20 cm before installing the experiment were: $\mathrm{pH}$ (in water) $=5.7 ; \mathrm{P}$ (Mehlich extractor $)=23.5 \mathrm{mg} \mathrm{dm}^{-3} ; \mathrm{K}$ (Mehlich extractor $)=108 \mathrm{mg} \mathrm{dm}^{-3} ; \mathrm{Na}=0.1 \mathrm{cmol}_{\mathrm{c}} \mathrm{dm}^{-3} ; \mathrm{Ca}=$ $1.4 \mathrm{cmol}_{\mathrm{c}} \mathrm{dm}^{-3} ; \mathrm{Mg}=0.6 \mathrm{cmol}_{\mathrm{c}} \mathrm{dm}^{-3} ; \mathrm{Al}=0.0 \mathrm{cmol}_{\mathrm{c}} \mathrm{dm}^{-3} ; \mathrm{H}+\mathrm{Al}=1.7 \mathrm{cmol}_{\mathrm{c}} \mathrm{dm}^{-3} ; \mathrm{SB}=2.4$ $\mathrm{cmol}_{\mathrm{c}} \mathrm{dm}^{-3} ; \mathrm{t}=2.4 \mathrm{cmol}_{\mathrm{c}} \mathrm{dm}^{-3} ; \mathrm{T}=4.1 \mathrm{cmol}_{\mathrm{c}} \mathrm{dm}^{-3} ; \mathrm{V}=58 \% ; \mathrm{B}=0.3 \mathrm{mg} \mathrm{dm}$; $\mathrm{Cu}=0.4 \mathrm{mg} \mathrm{dm}{ }^{-3} ; \mathrm{Fe}=16.0 \mathrm{mg} \mathrm{dm}^{-3} ; \mathrm{Mn}=32.5 \mathrm{mg} \mathrm{dm}{ }^{-3} ; \mathrm{Zn}=2.1 \mathrm{mg} \mathrm{dm}^{-3} ;$ $\mathrm{EC}_{\mathrm{e}}=0.7 \mathrm{dS} \mathrm{m}^{-1}$. Soil textural class was sandy loam clay (Sand $=68 \mathrm{dag} \mathrm{kg}^{-1} ;$ Silt $=11 \mathrm{dag} \mathrm{kg}^{-}$ ${ }^{1}$ and Clay $\left.=21 \mathrm{dag} \mathrm{kg}^{-1}\right)($ Embrapa, 2017).

'Pérola' pineapple seedlings (slips) were planted in April 2015 in a single row, at a spacing of $0.25 \mathrm{~m}$ between plants and $1.2 \mathrm{~m}$ between rows $\left(33,300\right.$ plants ha $\left.\mathrm{h}^{-1}\right)$. Soil correction and basal and top-dressing fertilizations were performed according to the soil analysis (Souza et al., 2007). During the experiment, cultivation and phytosanitary practices established for the crop were employed and there was low incidence of pests and diseases.

One month after planting, plants received foliar application of urea, zinc sulfate and potassium chloride $(\mathrm{KCl})$. After that, every two months, urea $\left(5 \mathrm{~g}^{\text {plant }}{ }^{-1}\right)$ and $\mathrm{KCl}$ $\left(2.5 \mathrm{~g} \mathrm{plant}^{-1}\right)$ were broadcasted.

Irrigation was applied through a drip system, using pressure-compensating emitters with nominal flow rate of $8 \mathrm{~L} \mathrm{~h}^{-1}$, spaced at $0.75 \mathrm{~m}$ apart, forming a continuous wet strip along plant rows. Until the fourth month after planting, irrigations were applied daily similarly in all plots, in order to maintain uniform soil water content and favor the initial growth of the seedlings and crop establishment. Then, irrigation depths started to be applied, and irrigation time was calculated based on crop evapotranspiration (ET $\mathrm{E}_{\mathrm{c}}$ ) (Santos et al., 2015) obtained using the reference evapotranspiration $\left(\mathrm{ET}_{\mathrm{o}}\right)$, determined daily through the Penman-Monteith method using data from a weather station installed approximately $200 \mathrm{~m}$ away from the experiment, and crop coefficient $(\mathrm{Kc})$, which was 0.8 at the initial stage of crop establishment and 1 for both the vegetative stage and after flower induction (reproductive stage), according to Santana et al. (2013).

The experiment was conducted in randomized blocks with five treatments consisting of the following irrigation depths: $100 \% \mathrm{ET}_{\mathrm{c}}$, using water with electrical conductivity $\left(\mathrm{EC}_{\mathrm{w}}\right)$ of $0.75 \mathrm{dS} \mathrm{m}^{-1}$ and C2S1 classification, and 50,75, 100 and $125 \% \mathrm{ET}_{\mathrm{c}}$, using water from a tubular well with $\mathrm{EC}_{\mathrm{w}}$ of $3.6 \mathrm{dS} \mathrm{m}^{-1}$, classified as C4S1 according to Ayers and Westcot (1985). Treatments had four replicates and the experimental unit consisted of four 8-m-long rows. Evaluations were made in plants from the central $4 \mathrm{~m}$ of the two central rows, totaling 26 
evaluated plants in the plot.

The water from tubular well has $\mathrm{pH}$ of $6.4,11.90 \mathrm{mEq} \mathrm{L}^{-1}$ of calcium, $9.54 \mathrm{mEq} \mathrm{L}^{-1}$ of magnesium, $0.48 \mathrm{mEq} \mathrm{L}^{-1}$ of potassium, $30.40 \mathrm{mEq} \mathrm{L}^{-1}$ of sodium, $0.00 \mathrm{mEq} \mathrm{L}^{-1}$ of carbonate, $4.10 \mathrm{mEq} \mathrm{L}^{-1}$ of bicarbonate and $34.80 \mathrm{mEq} \mathrm{L}^{-1}$ of chloride.

Pineapple flowering was artificially induced 13 months after planting, by applying ETHREL (240 $\mathrm{g} \mathrm{L}^{-1}$ of Ethephon), a synthetic growth regulator, precursor of the synthesis of ethylene, using a 20-L backpack sprayer. The backpack sprayer received $40 \mathrm{~mL}$ of ETHREL + $400 \mathrm{~g}$ of urea $(2 \%)$ to apply an estimated volume of $50 \mathrm{~mL}$ of the mixture inside the leaf rosette.

Chlorophyll $a$ fluorescence readings were made from August 2015 and September 2016 using a pulse-modulated fluorometer, model OS1-FL (OPTI-Sciences) in the morning (8 a.m.) and in the afternoon (2 p.m.). Clips used to measure chlorophyll fluorescence were positioned on the middle third of the ' $\mathrm{D}$ ' leaf, and the measurement was made after 5 min of dark adaptation, with an emission of a 0.3 -s-long saturation light pulse at a frequency of $0.6 \mathrm{KHz}$. Then, ground fluorescence $\left(\mathrm{F}_{0}\right)$, maximum fluorescence $(\mathrm{Fm})$, variable fluorescence $(\mathrm{Fv})$ and photochemistry efficiency (Fv/Fm) were recorded. During measurements, a clip for adapting chloroplast to the dark was used so that all photosystem II (PSII) reaction centers were "open" and heat loss was kept to a minimum (Strauss et al., 2006).

Additionally, readings were taken on light-adapted ' $D$ ' leaf, on which saturation pulses were applied to determine fluorescence under steady state (Fs), maximum fluorescence in the light-adapted state (Fms), variable fluorescence in the light-adapted state (Fvs), and quantum yield of PSII (Yield). Three dark-adapted readings and one light-adapted reading were taken at each identified plant. According to Lichtenthaler et al. (2005), photochemical quenching (qP), non-photochemical quenching (NPQ), and chlorophyll fluorescence decrease ratio $\left(\mathrm{R}_{\mathrm{Fd}}\right)$ were determined using the following Equations 1, 2 and 3:

$$
\begin{aligned}
& \mathrm{q}_{p}=(\mathrm{Fms}-\mathrm{F}) / \mathrm{Fvs} \\
& \mathrm{NPQ}=(\mathrm{Fm}-\mathrm{Fms}) / \mathrm{Fms} \\
& \mathrm{R}_{\mathrm{Fd}}=(\mathrm{Fm} / \mathrm{Fs})-1
\end{aligned}
$$

It is worth noting that the abbreviations qP (photochemical quenching), NPQ (nonphotochemical quenching) and $\mathrm{R}_{\mathrm{Fd}}$ (fluorescence decrease ratio) will be used in accordance with the international standard widely used in studies on chlorophyll fluorescence (Lichtenthaler et al., 2005).

Data were subjected to the analysis of variance and interactions were interpreted according to their significance. Variable means were compared by F-test and Tukey test $(p<0.05)$ for the factors reading times and irrigation depths, respectively; then, they were grouped by the ScottKnott criterion $(\mathrm{p}<0.05)$ for the factor evaluation season (months). Statistical analysis was performed with the statistical software 'R' (R Development Core Team, 2012).

\section{RESULTS AND DISCUSSION}

Quantum efficiency (Fv/Fm) of pineapple plants subjected to different irrigation depths with saline water over the months had a significant interaction between months and irrigation depths (Table 1). Nonetheless, significant differences were not observed across depths in all months of evaluation, except for November and December 2015. Irrigation depth $100 \%$ of ET using water with $\mathrm{EC}_{\mathrm{w}}$ of $0.75 \mathrm{dS} \mathrm{m}^{-1}$ differed from depths 50,100 and $125 \%$ of $\mathrm{ET}_{\mathrm{c}}$ using water with $3.6 \mathrm{dS} \mathrm{m}^{-1}$ in November; as for December, irrigation depth $100 \%$ of $\mathrm{ET}_{\mathrm{c}}$ using water of $\mathrm{EC}_{\mathrm{w}}$ of $0.75 \mathrm{dS} \mathrm{m}^{-1}$ differed from depths 50 and $75 \%$ of $\mathrm{ET}_{\mathrm{c}}$.

Furthermore, Fv/Fm values generated two groups within each depth, except for the depth

Rev. Ambient. Água vol. 15 n. 5, e2564 - Taubaté 2020 
$125 \%$ of $\mathrm{ET}_{\mathrm{c}}$. In general, lower values were verified in the last three months (Table 1).

Table 1. Quantum efficiency $(\mathrm{Fv} / \mathrm{Fm})$ in 'Pérola' pineapple plants subjected to different irrigation depths with non saline water and saline water over the months.

\begin{tabular}{cccccc}
\hline & \multicolumn{5}{c}{ Depths } \\
\cline { 2 - 6 } Month & $100 \% \mathrm{ET}_{\mathrm{c}}$ & $50 \% \mathrm{ET}_{\mathrm{c}}$ & $75 \% \mathrm{ET}_{\mathrm{c}}$ & $100 \% \mathrm{ET}_{\mathrm{c}}$ & $125 \% \mathrm{ET}_{\mathrm{c}}$ \\
\cline { 2 - 6 } & $0.75 \mathrm{dS} \mathrm{m}^{-1}$ & \multicolumn{5}{c}{$3.6 \mathrm{dS} \mathrm{m}{ }^{-1}$} \\
\hline Aug/15 & $0.57 \mathrm{~A}$ & $0.62 \mathrm{~A}$ & $0.56 \mathrm{~A}$ & $0.52 \mathrm{~B}$ & $0.56 \mathrm{~A}$ \\
$\mathrm{Sep} / 15$ & $0.57 \mathrm{~A}$ & $0.49 \mathrm{~B}$ & $0.55 \mathrm{~A}$ & $0.49 \mathrm{~B}$ & $0.53 \mathrm{~A}$ \\
$\mathrm{Oct} / 15$ & $0.57 \mathrm{~A}$ & $0.52 \mathrm{~B}$ & $0.54 \mathrm{~A}$ & $0.49 \mathrm{~B}$ & $0.51 \mathrm{~A}$ \\
Nov/15 & $0.65 \mathrm{Aa}$ & $0.54 \mathrm{Bb}$ & $0.58 \mathrm{Aab}$ & $0.55 \mathrm{Ab}$ & $0.54 \mathrm{Ab}$ \\
$\mathrm{Dec} / 15$ & $0.57 \mathrm{Aa}$ & $0.46 \mathrm{Bb}$ & $0.45 \mathrm{Bb}$ & $0.5 \mathrm{Bab}$ & $0.49 \mathrm{Aab}$ \\
$\mathrm{Feb} / 16$ & $0.6 \mathrm{~A}$ & $0.59 \mathrm{~A}$ & $0.57 \mathrm{~A}$ & $0.57 \mathrm{~A}$ & $0.6 \mathrm{~A}$ \\
$\mathrm{Mar} / 16$ & $0.56 \mathrm{~A}$ & $0.59 \mathrm{~A}$ & $0.61 \mathrm{~A}$ & $0.57 \mathrm{~A}$ & $0.53 \mathrm{~A}$ \\
$\mathrm{Apr} / 16$ & $0.53 \mathrm{~B}$ & $0.58 \mathrm{~A}$ & $0.59 \mathrm{~A}$ & $0.58 \mathrm{~A}$ & $0.54 \mathrm{~A}$ \\
$\mathrm{May} / 16$ & $0.52 \mathrm{~B}$ & $0.57 \mathrm{~A}$ & $0.58 \mathrm{~A}$ & $0.58 \mathrm{~A}$ & $0.5 \mathrm{~A}$ \\
$\mathrm{Jun} / 16$ & $0.55 \mathrm{~A}$ & $0.56 \mathrm{~A}$ & $0.56 \mathrm{~A}$ & $0.57 \mathrm{~A}$ & $0.5 \mathrm{~A}$ \\
$\mathrm{Jul} / 16$ & $0.48 \mathrm{~B}$ & $0.51 \mathrm{~B}$ & $0.52 \mathrm{~B}$ & $0.5 \mathrm{~B}$ & $0.52 \mathrm{~A}$ \\
Aug/16 & $0.49 \mathrm{~B}$ & $0.51 \mathrm{~B}$ & $0.5 \mathrm{~B}$ & $0.5 \mathrm{~B}$ & $0.5 \mathrm{~A}$ \\
$\mathrm{Sep} / 16$ & $0.46 \mathrm{~B}$ & $0.49 \mathrm{~B}$ & $0.5 \mathrm{~B}$ & $0.5 \mathrm{~B}$ & $0.49 \mathrm{~A}$ \\
\hline $\mathrm{cV}(\%)$ & & 40.27 & \\
\hline
\end{tabular}

* Means followed by same uppercase letters, in the column for months, belong to the same group by the Skott-Knott criterion at 5\% of significance level, and lowercase letters in the rows, for depths, do not differ from each other by the Tukey test at $5 \%$ of significance level.

Fluctuations in Fo, Fm and Fv contributed to the reduction in maximum quantum efficiency of PSII (Fv/Fm). Despite the difference between mean values resulting from the application of different irrigation depths, in the months of November and December, Fv/Fm in pineapple plants were below what is considered as optimal ( $\mathrm{Fv} / \mathrm{Fm}$ of $0.800 \pm 0.5)$, according to Bolhàr-Nordenkampf et al. (1989). Accordingly, Fv/Fm ratios indicate that the photochemical system of pineapple plants was altered. These low values of Fv/Fm are possibly due to higher photochemical energy on the leaf than the capacity of using it to drive the photosynthesis, which decreases Fv/Fm, i.e., leads to higher non-photochemical quenching. This decrease below the ideal is perhaps a defense mechanism to reduce light energy absorption and thereby decreasing the electron flow within the electron transport chain (Willadino et al., 2011).

Another important factor is that in the months that correspond to the reproductive stage, after flowering in June 2016, Fv/Fm had the lowest values.

Thus, it is evident that biotic and abiotic conditions under which the experiment was carried out damaged the photosynthetic apparatus, impairing the PSII over the time of exposition to stress (Freire et al., 2014), so the ecophysiological behavior of pineapple over the growing season in the semiarid might be a result of several environmental factors.

Regarding the readings on the light-adapted ' $\mathrm{D}$ ' leaves of pineapple, chlorophyll fluorescence under steady state (Fs), maximum fluorescence in the light-adapted state (Fms) and variable fluorescence in the light-adapted state (Fvs) were affected only by irrigation depth, regardless of reading time or evaluation season of these variables (Table 2). Fs, Fms and Fvs had the highest values for irrigation depth $100 \%$ of $\mathrm{ET}_{\mathrm{c}}$ using water with $\mathrm{EC}_{\mathrm{w}}$ of $0.75 \mathrm{dSm}^{-1}$. 
Table 2. Chlorophyll $a$ Fluorescence under steady state (Fs), maximum fluorescence in the light-adapted state (Fms), variable fluorescence in the light-adapted state (Fvs) and quantum yield of photosystem II (Yield) in 'Pérola' pineapple plants subjected to different irrigation depths with non saline water and saline water over the months.

\begin{tabular}{cccc}
\hline Depths & Fs & Fms & Fvs \\
\hline $100 \% \mathrm{ET}_{\mathrm{c}}\left(\mathrm{EC}_{\mathrm{w}}=0.75 \mathrm{dSm}^{-1}\right)$ & $403.9 \mathrm{a}$ & $688.8 \mathrm{a}$ & $284.8 \mathrm{a}$ \\
$50 \% \mathrm{ET}_{\mathrm{c}}\left(\mathrm{EC}_{\mathrm{w}}=3.6 \mathrm{dS} \mathrm{m}^{-1}\right)$ & $354.6 \mathrm{~b}$ & $547.9 \mathrm{~b}$ & $193.2 \mathrm{~b}$ \\
$75 \% \mathrm{ET}_{\mathrm{c}}\left(\mathrm{EC}_{\mathrm{w}}=3.6 \mathrm{dS} \mathrm{m}^{-1}\right)$ & $380.1 \mathrm{ab}$ & $589.5 \mathrm{~b}$ & $209.4 \mathrm{~b}$ \\
$100 \% \mathrm{ET}_{\mathrm{c}}\left(\mathrm{EC}_{\mathrm{w}}=3.6 \mathrm{dS} \mathrm{m}^{-1}\right)$ & $363.6 \mathrm{~b}$ & $572.1 \mathrm{~b}$ & $208.5 \mathrm{~b}$ \\
$125 \% \mathrm{ET}_{\mathrm{c}}\left(\mathrm{EC}_{\mathrm{w}}=3.6 \mathrm{dS} \mathrm{m}^{-1}\right)$ & $374.0 \mathrm{ab}$ & $595.2 \mathrm{~b}$ & $221.3 \mathrm{~b}$ \\
\hline $\mathrm{CV}(\%)$ & 29.78 & 48.94 & 91.74 \\
\hline
\end{tabular}

Means followed by the same letters, in the columns, do not differ from each other by Tukey test at $5 \%$ of significance level.

Fs, Fms and Fvs were higher in plants irrigated using water with $\mathrm{EC}_{\mathrm{w}}$ of $0.75 \mathrm{dSm}^{-1}$ (Table 2), although Yield did not have the same tendency. It is noted that under field conditions, salinity stress is enhanced by other environmental adversities, such as high temperatures, low relative humidity and high wind speed (Figure 1).

Chlorophyll fluorescence results presented herein prove that pineapple plants subjected to abiotic stresses such as salinity, high temperatures and low relative humidity exhibit changes in the functional state of thylakoid membranes of chloroplasts. These changes have an impact on fluorescence and, consequently, on quantum efficiency $(\mathrm{Fv} / \mathrm{Fm})$ and on potential quantum yield (Yield) (Cha-Um and Kirmanee, 2011). In spite of Fv/Fm being below the ideal, the pineapple proved to tolerate salinity since Yield, $\mathrm{qP}, \mathrm{NPQ}$ and RFd results indicate a high efficiency at converting light energy into chemical energy, without differences between using water with $\mathrm{EC}_{\mathrm{w}}$ of 0.75 and $3.6 \mathrm{dS} \mathrm{m}^{-1}$ for irrigation.

Quantum photosynthetic yield of PSII (Yield), photochemical quenching, (qp) nonphotochemical quenching (NPQ) and fluorescence decrease ratio $\left(\mathrm{R}_{\mathrm{Fd}}\right)$ were not influenced by irrigation depths (Table 3). There was only the effect of the time factor. Yield and $\mathrm{R}_{\mathrm{Fd}}$ were higher at 2 p.m. while $\mathrm{q}_{\mathrm{p}}$ was higher at 8 a.m. As for NPQ, no significant differences were observed.

Table 3. Quantum yield of photosystem II (Yield), photochemical quenching ( $\mathrm{q}_{\mathrm{p}}$ ), non-photochemical quenching (NPQ) and fluorescence decrease ratio $\left(\mathrm{R}_{\mathrm{Fd}}\right)$ in 'Pérola' pineapple plants subjected to different irrigation depths with non-saline water and saline water.

\begin{tabular}{ccccccccc}
\hline \multirow{2}{*}{ Depths } & \multicolumn{2}{c}{ Yield } & \multicolumn{2}{c}{$\mathrm{q}_{\mathrm{P}}$} & \multicolumn{2}{c}{ NPQ } & \multicolumn{2}{c}{$\mathrm{R}_{\mathrm{Fd}}$} \\
\cline { 2 - 8 } & $8 \mathrm{a} . \mathrm{m}$. & $2 \mathrm{p} . \mathrm{m}$. & $8 \mathrm{a} . \mathrm{m}$. & $2 \mathrm{a} . \mathrm{m}$. & $8 \mathrm{a} . \mathrm{m}$. & $2 \mathrm{p} . \mathrm{m}$. & $8 \mathrm{a} . \mathrm{m}$. & $2 \mathrm{p} . \mathrm{m}$. \\
\hline $100 \% \mathrm{ET}_{\mathrm{c}}\left(\mathrm{EC}_{\mathrm{w}}=0.75 \mathrm{dS} \mathrm{m}^{-1}\right)$ & $0.26 \mathrm{Ab}$ & $0.30 \mathrm{Aa}$ & $0.44 \mathrm{Aa}$ & $0.33 \mathrm{Ab}$ & $0.30 \mathrm{Aa}$ & $0.36 \mathrm{Aa}$ & $1.48 \mathrm{Ab}$ & $2.28 \mathrm{Aa}$ \\
$50 \% \mathrm{ET}_{\mathrm{c}}\left(\mathrm{EC}_{\mathrm{w}}=3.6 \mathrm{dS} \mathrm{m}^{-1}\right)$ & $0.24 \mathrm{Ab}$ & $0.30 \mathrm{Aa}$ & $0.44 \mathrm{Aa}$ & $0.34 \mathrm{Ab}$ & $0.31 \mathrm{Aa}$ & $0.35 \mathrm{Aa}$ & $1.50 \mathrm{Ab}$ & $2.24 \mathrm{Aa}$ \\
$75 \% \mathrm{ET}_{\mathrm{c}}\left(\mathrm{EC}_{\mathrm{w}}=3.6 \mathrm{dS} \mathrm{m}^{-1}\right)$ & $0.24 \mathrm{Ab}$ & $0.34 \mathrm{Aa}$ & $0.45 \mathrm{Aa}$ & $0.34 \mathrm{Ab}$ & $0.30 \mathrm{Aa}$ & $0.31 \mathrm{Aa}$ & $1.39 \mathrm{Ab}$ & $2.12 \mathrm{Aa}$ \\
$100 \% \mathrm{ET}_{\mathrm{c}}\left(\mathrm{EC}_{\mathrm{w}}=3.6 \mathrm{dS} \mathrm{m}^{-1}\right)$ & $0.26 \mathrm{Ab}$ & $0.31 \mathrm{Aa}$ & $0.45 \mathrm{Aa}$ & $0.38 \mathrm{Ab}$ & $0.27 \mathrm{Aa}$ & $0.30 \mathrm{Aa}$ & $1.38 \mathrm{Ab}$ & $1.92 \mathrm{Aa}$ \\
$125 \% \mathrm{ET}_{\mathrm{c}}\left(\mathrm{EC}_{\mathrm{w}}=3.6 \mathrm{dS} \mathrm{m}^{-1}\right)$ & $0.27 \mathrm{Aa}$ & $0.30 \mathrm{Aa}$ & $0.43 \mathrm{Aa}$ & $0.37 \mathrm{Ab}$ & $0.29 \mathrm{Aa}$ & $0.31 \mathrm{Aa}$ & $1.43 \mathrm{Ab}$ & $1.95 \mathrm{Aa}$ \\
\hline $\mathrm{CV}(\%)$ & 38.40 & \multicolumn{2}{c}{28.56} & & 51.54 & & 53.51 \\
\hline
\end{tabular}

Means followed by the same letters, in the rows, do not differ from each other by F-test at $5 \%$ of significance level. Means followed by the same uppercase letters in the column for months do not differ from each other by the Tukey test at $5 \%$ of significance level.

$\mathrm{R}_{\mathrm{Fd}}$ is used as an indicator of the Calvin cycle activity and related processes. When $\mathrm{R}_{\mathrm{Fd}}$ is below 1, $\mathrm{CO}_{2}$ fixation is believed to be severely impaired (Lichtenthaler et al., 2005; Perera- 
Castro et al., 2018). Thus, salinity did not have an effect on $\mathrm{CO}_{2}$ fixation under the experimental conditions of this study. Moreover, the higher values of $\mathrm{R}_{\mathrm{Fd}}$ at 2 p.m. possibly indicate a high amount of internal $\mathrm{CO}_{2}$ coming from the decarboxylation of malic acid, which favors Calvin cycle activity (Borland et al., 2014).

$\mathrm{R}_{\mathrm{Fd}}$ and $\mathrm{q}_{\mathrm{p}}$ results agree with $\mathrm{CO}_{2}$ fixation stages described for CAM plants (Osmond, 1978; Borland et al., 2014). Stage II begins with the presence of light at which $\mathrm{CO}_{2}$ is taken up from the atmosphere through the stomata still open. Then, at Stage III, as temperature and radiation rise, the stomata close (increasing stomatal conductance) and internal $\mathrm{CO}_{2}$ uptake ceases, which explains the lower values of RFd at 8 p.m. At this stage, malate stored in vacuoles during Stage $\mathrm{I}$ is decarboxylated, internal $\mathrm{CO}_{2}$ is released and assimilated, and starch is produced; hence, the increased values of $R_{F d}$ at 2 p.m.

NPQ indicates light energy quenching as heat in the antenna complex of PSII. In this study, salinity had no effect on energy quenching, indicating ideal use of excitation energy for $\mathrm{q}_{\mathrm{p}}$.

Salinity stress reduces photosynthetic yield in C3 plants as a result of closing stomata and inhibition of photosynthetic carbon fixation (Tatagiba et al., 2014). However, since the pineapple has characteristics of a CAM plant, as shown in this study by the values of Yield, $R_{F d}$ and $\mathrm{q}_{\mathrm{p}}$, it is suggested that applying saline water does not have a negative impact on fluorescence characteristics evaluated over the study. Decreases in yield observed when applying saline irrigation water under semiarid conditions (Brito et al., 2017) might be due to other salinity-related effects such as changes in nutrient uptake, transport, assimilation and distribution throughout the plant (Santos and Brito, 2016).

Findings shown herein are relevant because they broaden existing knowledge about pineapple physiology and enable the association with other research results, thereby improving management practices to increase yield of crops irrigated with low-quality water and grown under semiarid conditions.

\section{CONCLUSIONS}

Fluctuations in quantum efficiency $(\mathrm{Fv} / \mathrm{Fm})$ occur over the cycle of 'Pérola' pineapple grown under semiarid conditions.

Energy use for photosynthetic processes of 'Pérola' pineapple plants is not affected by irrigation using saline water with electrical conductivity of $3.6 \mathrm{dS} \mathrm{m}^{-1}$.

The results of the evaluated physiological characteristics indicate resilience of the pineapple in cultivation under irrigation water salinity conditions. Thus, new research must be developed to adjust the cultivation of pineapple with saline water in the semiarid region of Bahia.

\section{ACKNOWLEDGEMENTS}

This study was supported by the Coordination for the Improvement of Higher Education Personnel - Brazil (CAPES) (grant number 001) and by the National Council for Scientific and Technological Development (CNPq) (Project number 467901/2014-7).

\section{REFERENCES}

AYERS, R. S.; WESTCOT, D. W. A qualidade da água na agricultura. Campina Grande: UFPB, 1985. 218p.

BOLHÀR-NORDENKAMPF, H. R.; LONG, P.; BAKER, N. R.; OQUIST, G.; SCHREIBER, U.; LECHNER, E. G. Chlorophyll fluorescence as probe of the photosynthetic competence of leaves in the field: a review of current instrumentation. Functional Ecology, v. 3, n. 1, pp. 497-514, 1989. https://doi.org/10.2307/2389624 
BORLAND, A. M.; HARTWELL, J.; WESTON, D. J.; SCHLAUCH, K. A.; TSCHAPLINSKI, T. J.; TUSKAN, G. A.; YANG, X.; CUSHMAN J. C. Engineering crassulacean acid metabolism to improve water-use efficiency. Trends in Plant Science, v. 19, n. 5, p. 327 338, 2014. https://doi.org/10.1016/j.tplants.2014.01.00

BRITO, C. F. B.; SANTOS, M. R. dos; FONSECA, V. A.; ARANTES, A. M.; ALMEIDA, J. R. Physiological characteristics and yield of 'Pérola' pineapple in the semiarid region. Revista Brasileira de Engenharia Agrícola e Ambiental, v. 21, n. 12, p. 834-839, 2017. http://dx.doi.org/10.1590/1807-1929/agriambi.v21n12p834-839

CARR, M. K. V. The water relations and irrigation requirements of pineapple (Ananas comosus var. comosus): a review. Experimental Agriculture, v. 48, n. 4, p. 488-501, 2012. http://dx.doi.org/10.1017/S0014479712000385

CHA-UM, S.; KIRDMANEE, C. Remediation of salt-affected soil by the addition of organic matter: an investigation into improving glutinous rice productivity. Scientia Agrícola, v. 68, n. 4, p. 406-410, 2011. http://dx.doi.org/10.1590/S0103-90162011000400003

COUTO, T. R.; SILVA, J. R.; MORAES C. R. O.; RIBEIRO, M. S.; NETTO, A. T.; CARVALHO, V. S.; CAMPOSTRINI, E. Photosynthetic metabolismo and growth of pineapple (Ananas comosus L. Merr.) cultivated ex vitro. Theoretical and Experimental Plant Physiology, v. 28, n. 3, p. 333-339, 2016. http://dx.doi.org/10.1007/s40626-0160062-X

CRUZ, L. I. B.; CRUZ, M. C. M.; FERREIRA, E. A.; CASTRO, G. D. M.; ALMEIDA, M. O. Eficiência quântica do fotossistema II de mudas de abacaxizeiro 'Imperial' em resposta a associação com Piriformospora indica e herbicidas. Revista Brasileira de Fruticultura, v. 36, n. 4, p. 794-804, 2014. http://dx.doi.org/10.1590/0100-2945-411/13

DÍEZ, M. C.; MORENO, F.; GANTIVA, E. Effects of light intensity on the morphology and CAM photosynthesis of Vanilla planifolia Andrews. Revista Facultad Nacional de Agronomía, v. 70, n. 1, p.8023-8031, 2017. http://dx.doi.org/10.15446/rfna.v70n1.61736

ELHAG, A. Z.; ELZAIN, H. Sodium chloride tolerance of pineapple (Ananas comosus 1. Mirrl.) In vitro. Journal of Applied Agricultural Research, v. 4, n. 2, p. 105-110, 2012.

EMBRAPA. Manual de métodos de análise de solo. 3. ed. Brasília: Embrapa, 2017. 573p.

FRANCO, L. R. L.; MAIA, V. M.; LOPES, O. P.; FRANCO, W. T. N.; SANTOS, S. R. Crescimento, produção e qualidade do abacaxizeiro 'Pérola' sob diferentes lâminas de irrigação. Revista Caatinga, v. 27, n. 2, p. 132-140, 2014.

FREIRE, J. L. O.; DIAS, T. J.; CAVALCANTE, L. F.; FERNANDES, P. D.; NETO, A. J. L. Rendimento quântico e trocas gasosas em maracujazeiro amarelo sob salinidade hídrica, biofertilização e cobertura morta. Revista Ciência Agronômica, v. 45, n.1, p. 82-91, 2014.

GOLTSEV, V. N.; KALAJI, H. M.; PAUNOVA, M.; BĄBA, W.; HORACZEK, T.; MOJSKI, J.; KOCIEL, H.; ALLAKHVERDIEV, S. I. Variable chlorophyll fluorescence and its use for assessing physiological condition of plant photosynthetic apparatus. Russian Journal of Plant Physiology, v. 63, n. 6, p. 869-893, 2016. https://doi.org/10.1134/S1021443716050058

IBGE. Censo Agropecuário. 2020. Available at: http://www.sidra.ibge.gov.br. Access: 13 July 2020. 
LICHTENTHALER, H. K.; BUSCHMANN, C.; KNAPP, K. How to correctly determine the different chlorophyll fluorescence parameters and the chlorophyll fluorescence decrease ratio $\mathrm{R}_{\mathrm{Fd}}$ of leaves with the PAM fluorometer. Photosynthetica, v. 43, n. 3, p. 379-393, 2005. https://doi.org/10.1007/s11099-005-0062-6

MAIA, V. M.; OLIVEIRA, F. S.; PEGORARO, R. F.; ASPIAZÚ, I.; PEREIRA, M. C. T. 'Pérola' pineapple growth under semiarid climate conditions. Acta Horticulture, v. 1111, p. 267-263, 2016. http://dx.doi.org/10.17660/ActaHortic.2016.1111.38

MOTA, M. F. C.; PEGORARO, R. F.; BATISTA, P. S. C.; PINTO, V. de O.; MAIA, V. M.; SILVA, D. F. da. Macronutrients accumulation and growth of pineapple cultivars submitted to aluminum stress. Revista Brasileira de Engenharia Agrícola e Ambiental, v. 20 , n. 11, p. 978-983, 2016. http://dx.doi.org/10.1590/18071929/agriambi.v20n11p978-983

MURCHIE, E. H.; LAWSON, T. Chlorophyll fluorescence analysis: A guide to good practice and understanding some new applications. Journal of Experimental Botany, v. 64, n. 13, p. 3983-3998, 2013. http://dx.doi.org/10.1093/jxb/ert208

OSMOND, C. B. Crassulacean acid metabolism: A curiosity in context. Annual Review of $\begin{array}{llllllll}\text { Plant Physiology, } & \text { v. } 29, \quad \text { n. } 3, & \text { p. } & 379-414, & \end{array}$ https://doi.org/10.1146/annurev.pp.29.060178.002115

PEGORARO, R. F.; SOUZA, B. A. M.; MAIA, V. M.; AMARAL, U.; PEREIRA, M. C. T. Growth and production of irrigated 'Vitória' pineapple grown in semiarid conditions. Revista Brasileira de Fruticultura, v. 36, n. 3, p. 693- 703, 2014. http://dx.doi.org/10.1590/0100-2945-265/13

PERERA-CASTRO, A. V.; BRITO, P.; GONZÁLEZ-RODRÍGUEZ, A. M. Changes in thermic limits and acclimation assessment for an alpine plant by chlorophyll fluorescence analysis: Fv/Fm vs. Rfd. Photosynthetica, v. 56, n. 2, p. 527-536, 2018. https://dx.doi.org/10.1007/s11099-017-0691-6

$\mathrm{R}$ DEVELOPMENT CORE TEAM. $\mathbf{R}$ a language and environment for statistical computing. Vienna: R Foundation for Statistical Computing, 2012.

SANTANA, M. J. de; SOUZA, O. P. de; CAMARGOS, A. E. V.; ANDRADE, J. P. R. Coeficientes de cultura do abacaxizeiro nas condições edafoclimáticas de Uberaba, MG. Revista Brasileira de Engenharia Agrícola e Ambiental, v. 17, n. 6, p.602-607, 2013. http://dx.doi.org/10.1590/S1415-43662013000600005

SANTOS, M. R. dos.; BRITO, C. F. B. Irrigação com Água Salina, Opção Agrícola Consciente. Revista Agrotecnologia, v. 7, n. 1, p. 33-41, 2016. https://dx.doi.org/10.12971/2179-5959/agrotecnologia.v7n1p33-41

SANTOS, M. R. dos; NEVES, B. R.; SILVA, B. L.; DONATO, S. L. R. Yield, water use efficiency and physiological characteristic of 'Tommy Atkins' mango under partial root zone drying irrigation system. Journal of Water Resourceand Protection, v. 7, n. 13, p. 1029-1037, 2015. http://dx.doi.org/10.4236/jwarp.2015.713084

SOUZA, C. B. de; SILVA, BERNARDO B. da; AZEVEDO, P. V. de. Crescimento e rendimento do abacaxizeiro nas condições climáticas dos Tabuleiros Costeiros do Estado da Paraíba. Revista Brasileira de Engenharia Agrícola e Ambiental, v. 11, n. 2, p. 134141, 2007. http://dx.doi.org/10.1590/S1415-43662007000200002 
STRAUSS, A. J.; KRÜGER, G. H. J.; STRASSER, R. J.; VAN HEERDEN, P. D. R. Ranking of dark chilling tolerance in soybean genotypes probed by the chlorophyll a fluorescence transient O-J-I-P. Environmental and Experimental Botany, v. 56, n. 2, p. 147-157, 2006. https://doi.org/10.1016/j.envexpbot.2005.01.011

TATAGIBA, S. D.; MORAES, G. A. B. K.; NASCIMENTO, K. J. T.; PELOSO, A. F. Limitações Fotossintéticas em Folhas de Plantas de Tomateiro Submetidas a Crescentes Concentrações Salinas. Engenharia na Agricultura, v. 22, n. 2, p. 138-149, 2014.

TEDESCO, M. J.; GIANELLO, C.; BISSANI, C. A.; BOHNEN, H.; VOLKWEISS, S. J. Análise de solos, plantas e outros materiais. Porto Alegre: Universidade Federal do Rio Grande do Sul, 1995. 174p. (Boletim Técnico, 5).

VIEIRA, D. A. P.; PORTES, T. A.; STACCIARINI-SERAPHIN, E.; TEIXEIRA, J. B. Fluorescência e teores de clorofilas em abacaxizeiro cv. Pérola submetido a diferentes concentrações de sulfato de amônio. Revista Brasileira de Fruticultura, v. 32, n. 2, p. 360-368, 2010. http://dx.doi.org/10.1590/S0100-29452010005000061

WILLADINO, L.; OLIVEIRA FILHO, R. A.; SILVA JUNIOR, E. A.; GOUVEIA NETO, A.; CAMARA, T. R. Estresse salino em duas variedades de cana-de-açúcar: enzimas do sistema antioxidativo e fluorescência da clorofila. Revista Ciência Agronômica, v. 42, n. 2, p. 417-422, 2011.

ZHANG, J.; LIU, J.; MING, R. Genomic analyses of the CAM plant pineapple. Journal of Experimental Botany, v. 65, n. 13, p. 01-10, 2014. https://doi.org/10.1093/jxb/eru101 